\title{
Antynomie szkolnych i pozaszkolnych lektur
}

\author{
School antinomies and extracurricular reading
}

\author{
|Zofia Zasacka \\ Biblioteka Narodowa, Instytut Książki i Czytelnictwa; \\ Instytut Badań Edukacyjnych
}

\begin{abstract}
The paper reviews the students' attitudes towards literature present on polish language lessons. It focused on the components forming these attitudes, which come from antinomies between reading experiences in leisure time and compulsory school reading. The paper is based on the results of the study on children and young people readership, particularly the results of qualitative stage of that research: 48 IDI (Individual In-depth Interviews) with students at the end of education in primary school and lower secondary school. There are put some tips for teachers of Polish language and literature supporting them in evoking students reading motivations, specially intrinsic ones.

Key words: readership, reading motivations, lower secondary school, primary school, literature, education, strategies of teaching literature in school.

Streszczenie: Artykuł jest poświęcony uczniowskim postawom wobec literatury pięknej obecnej na lekcjach języka polskiego. Skupiono się na tych elementach budujących owe postawy, które wynikają z rozbieżności między doświadczeniami czytelniczymi zdobywanymi poza szkolnymi obowiązkami a czytaniem w ich ramach. Wykorzystano wyniki badania czytelnictwa dzieci i młodzieży, szczególnie posłużono się analizami wyników jakościowego etapu - 48 wywiadów indywidualnych przeprowadzonych wśród uczniów kończących naukę w szkole podstawowej i gimnazjum. W artykule są sformułowane zalecenia dla dydaktyki polonistycznej sugerujące strategie dydaktyczne sprzyjające rozbudzaniu u uczniów motywacji czytelniczych, szczególnie motywacji wewnętrznych.
\end{abstract}

Słowa kluczowe: czytelnictwo, motywacje czytelnicze, szkoła podstawowa, gimnazjum, literatura, edukacja, dydaktyka literatury pięknej w szkole.

Nauczyciele, wskazując na najważniejsze trudności w swojej pracy dydaktycznej, wymieniają między innymi nieczytanie lektur szkolnych przez uczniów (Bordzoł, Zasacka 2014). Ostatnie wyniki badania czytelnictwa dzieci i młodzieży rzucają trochę światła na siłę i przyczyny uczniowskiego 
oporu wobec szkolnego czytania. Pozwalają też spojrzeć na szkolną sytuację komunikacji czytelniczej z perspektywy samych uczniów.

W Instytucie Badań Edukacyjnych przy współpracy Biblioteki Narodowej przeprowadzono kolejną edycję ogólnopolskiego badania czytelnictwa gimnazjalistów, która dodatkowo objęła swoim zasięgiem trzynastolatków uczniów szóstej klasy szkoły podstawowej (Zasacka 2014). Celem badania była ocena społecznego zasięgu książki wśród uczniów kończących szkołę podstawową i gimnazjum, obserwacja biografii oraz postaw czytelniczych nastolatków. Analizy wyników badania pozwoliły między innymi na opisanie miejsca aktywności czytelniczej w uczniowskiej codzienności; ukazanie czynników różnicujących motywacje czytelnicze dzieci i młodzieży; stosunku wobec lektur związanych z realizacją obowiązku szkolnego oraz wyróżnienie wspólnego obszaru książkowych doświadczeń lekturowych.

Badanie składało się $\mathrm{z}$ dwóch etapów: jakościowego i ilościowego. $\mathrm{Na}$ jakościowym etapie badania przeprowadzono 48 indywidualnych wywiadów pogłębionych (IDI - Individual Depth Interview) wśród uczniów wywodzących się z różnych społeczno-kulturowych środowisk: wiejskiego, $\mathrm{z}$ małego i dużego miasta. Badanie ilościowe polegało na realizacji ankiety audytoryjnej wśród uczniów jednego wylosowanego oddziału VI klasy szkoły podstawowej i III klasy gimnazjalnej. Prowadzone było w listopadzie 2013 r. Badaniem zostali objęci uczniowie 202 szkół w całej Polsce, w tym 100 szkół podstawowych oraz 102 szkół gimnazjalnych. Uczestniczyło w nim łącznie 3537 uczniów, w tym 1721 uczniów szkół podstawowych oraz 1816 uczniów gimnazjów.

Analiza wyników dowodzi, że uczniowie reprezentują bardzo zróżnicowane postawy wobec czytania książek, wyborów lekturowych i sposobów uczestnictwa w społecznym obiegu książki. Po jednej stronie znajdują się czytający codziennie aktywni czytelnicy, po drugiej ci, którzy nie czytają. Wśród czynników różnicujących te postawy na pierwszy plan wysuwa się płeć nastolatków oraz kapitał kulturowy związany z poziomem wykształcenia rodziców i wielkością książkowych zasobów będących w posiadaniu rodziny. Im ten kapitał jest mniejszy, tym większe jest prawdopodobieństwo nieczytania książek przez nastolatków. Również wraz z dorastaniem nastolatków powiększają się różnice w formach aktywności czytelniczej, szczególnie podejmowanej $\mathrm{w}$ czasie wolnym. Zmienia się nastawienie do czytania, maleje publiczność czytająca w środowiskach o najniższym kapitale kulturowym, szczególnie wśród chłopców mieszkających na wsi. Grupa tych ostatnich poszerza się wraz z dorastaniem - stanowi 14\% ogółu badanych gimnazjalistów. Niepokojące jest to, że aż co piąty piętnastoletni chłopiec omija czytanie szkolne i nie ma nawyku sięgania po książkę z własnego wyboru; nie czyta dla przyjemności (Zasacka 2014).

$\mathrm{W}$ artykule zostaną przedstawione obserwacje płynące $\mathrm{z}$ prezentowanego badania czytelnictwa, dotyczące uczniowskich postaw wobec czytania w ogóle, a szczególnie czytania w ramach obowiązku lekcyjnego oraz 
implikacje, jakie wynikają z nich dla polonistyki szkolnej. Wykorzystane zostały przede wszystkim analizy jakościowego etapu badania - 48 indywidualnych wywiadów pogłębionych.

\section{Przymus kojarzy się z nudą}

Badani uczniowie - młodsi i starsi, pochodzący ze wszystkich środowisk, zarówno mający bogate lekturowe doświadczenia, jak i czytelnicy sporadyczni - byli podobnie uprzedzeni do książek, które musieli czytać z obowiązku. Problem ten dotyczy dobrych uczniów, o wysokich kompetencjach literackich, a także słabych, mających trudności z czytaniem skomplikowanych tekstów. Oto charakterystyczna odpowiedź chłopca z wielkomiejskiego gimnazjum, aktywnego czytelnika czasu wolnego:

Sięgnąłbyś po „Pana Tadeusza”, gdyby nie był lekturą? - Tak. Bo wtedy nie byłoby to takie przymusowe. Nienawidzę, jak mi się coś każe robić. Po prostu z czystej ludzkiej ciekawości, zobaczyłbym, co to jest, przeczytałbym... (G39-3F26-0).

Podobny tok argumentowania przyjęła uczennica szkoły podstawowej:

A zastanów się teraz, jakich książek unikasz albo nie chciałabyś czytać. Nie chcesz czytać. - Zazwyczaj to lektur. - [...] Dlatego, że tak jakoś jak sama wypożyczę, to przeczytam. Ale jak np. ktoś mi każe, tak samo jak na polskim, to tak jakoś nie chce mi się (P14-6A16-1).

Uczniowie nie są zaintrygowani treścią, przesłaniem czytanego utworu, rzadko też wartości edukacyjne zawarte w lekturach szkolnych wpływają na ich motywacje czytelnicze. Choć posiadają różne pozaszkolne zainteresowania lekturowe, to obowiązek szkolny, czytanie na określony termin, sprawiają, że nie pojawia się inne zaciekawienie tekstem, niż to wynikające $\mathrm{z}$ oczekiwania na zewnętrzną nagrodą. W odczuciu uczniów zazwyczaj potwierdza się przekonanie, że lektura będzie nudna. Jednocześnie spodziewają się jej rutynowego omawiania i skupiają przede wszystkim na tym, aby dobrze wypaść na sprawdzianie ze znajomości treści. W takiej sytuacji przydatna mogłaby być wiedza na temat tego, dlaczego tekst warto przeczytać, co jest w nim interesującego. Zaangażowaniu w czytanie, stanowiącemu niezbędny element motywacji wewnętrznej, sprzyja świadomość zasadności powodów poznawanych i analizowanych treści (Guthrie, Wigfield 2000, Brophy 2010). Jeśli uczniowie są świadomi powodów, dla których powinni opanować określone umiejętności, z jakiej przyczyny zostały wybrane takie, a nie inne utwory literackie, to wiedza ta sprzyja pozytywnej motywacji do wykonywania poleceń nauczyciela, pomaga także rozbudzić ciekawość, zainteresowanie lekturami. Takie okoliczności mogą ich zmobilizować do pokonywania ewentualnych trudności w rozumieniu i przyswajaniu treści omawianych podczas lekcji.

Często jednak świadomość, że dany utwór jest „wartościowy”, nie okazuje się wystarczającą zachętą. To problem szczególnie gimnazjalistów, którym jako lektury proponuje się przede wszystkim literaturę klasyczną. 
Niektórzy starsi uczniowie, pomimo posiadania bogatego doświadczenia czytelniczego i przekonania o wartościach poznawczych lektury, odrzucają dawne teksty. Są to sytuacje porażki polonistyki szkolnej. Oto charakterystyczna wypowiedź uczennicy, aktywnej czytelniczki, chętnie czytającej poezję:

„Syzyfowe prace”. Nudne piekielnie. Znaczy ja rozumiem, że ze względów historycznych powinniśmy poznać tamte czasy, dlatego to jest lektura, ale naprawdę mogliby wybrać coś innego, bo to jest piekielnie nudne. Tego się czytać nie chce. Ja czytałam to i nie przeczytałam pierwszej strony nawet, bo zasnęłam 2 razy. Pierwszy raz mnie się tak zdarzyło, więc tak, tę lekturę bym wywaliła, zdecydowanie (G39-3F10-1).

Pomiar siły odczuwania motywacji czytelniczych uczniów przeprowadzony w omawianym badaniu dowiódł, że motywacje zewnętrzne, uruchomiające czytanie dla nagrody niezwiązanej z samym tekstem, słabną wraz z wiekiem uczniów - nawet dziewczęta nie czytają już tak pilnie z myślą o lepszej ocenie. Aby lektura utworów szkolnych została podjęta, konieczne jest odczuwanie przez ucznia sprzyjających im motywacji wewnętrznych. Tekst powinien zaciekawić czytelnika, rozbudzić jego zainteresowanie, utrzymać uwagę. Co to oznacza? Co może pomóc, a co stanowić przeszkodę w rozbudzeniu motywacji wewnętrznych ucznia?

\section{Kłopotliwe cechy szkolnych lektur}

Uczniowie szkół podstawowych i gimnazjaliści bardzo rzadko wykorzystują do opisu cenionych czy nielubianych książek terminy teoretycznoliterackie, posługują się językiem nie znawcy, ale czytelnika amatora. Wśród wartości przypisywanych udanej lekturze wskazują przede wszystkim - obok wartości rozrywkowych - na walory lekturowe (Straus 2005, 125-126), wśród których istotnym elementem jest język utworu.

\section{Obcy język}

Podczas pomiaru siły odczuwanych przez uczniów motywacji czytelniczych na etapie ilościowym badania i analizy komponentów tych motywacji ujawniono, że to język czytanego tekstu może zniechęcać do czytania nawet starsze dziewczęta, z reguły chętniej podejmujące wyzwania lekturowe. Również chłopcy w udzielanych wywiadach podkreślali, że niezależnie od tematyki utworu, jego język stanowi zasadniczą trudność. Buduje on barierę po pierwsze wtedy, kiedy służy przedstawianiu świata nieznanego uczniom z doświadczenia, a odczucie obcości wzmaga wykorzystanie stylizacji, archaizmów, dialektów, neologizmów czy nieznanej frazeologii; po drugie wówczas, gdy tekst napisany jest oryginalnym, niestosowanym współcześnie językiem historycznym. Według uczniów książka powinna być przede wszystkim napisana łatwym, przystępnym, zrozumiałym dla czytelnika językiem. Łatwy oznacza brzmienie najbliższe językowi potocznemu, 
codziennemu, znanemu z doświadczenia. Takie oczekiwania posiadają nawet uczniowie o bogatych doświadczeniach lekturowych. Oto przykładowa opinia:

Po pierwsze, uaktualnić tę listę, a nie trzymać te same przez ostatnie czterdzieści parę lat. Skorzystać bardziej z ksiązek, które sq aktualne. Które teraz bardziej zainteresowały młodzież. Które będa napisane prostszym raczej językiem (G39-3F26-0).

\title{
Nieciekawa historia
}

Uczniowie poszukują w lekturach szkolnych tego samego, czego w utworach czytanych poza szkolnym obowiązkiem, wybieranych spontanicznie: częściej wartości rozrywkowych, niż poznawczych, etycznych czy artystycznych. To nie tyle literackie przesłanie, co „wciągająca” fabuła z przygodami, suspensem, napięciem oraz przystępna forma wpływają na pozytywną ocenę tekstu. Brak interesującej dla nich historii jest kolejnym powodem odrzucenia lektury. Jest ona odbierana jako nudna, po pierwsze, gdy traktuje o problemach dla uczniów nieciekawych i odległych, niezrozumiałych, po drugie, kiedy brakuje w niej akcji (albo akcja zbyt wolno się rozwija), jest za mało dialogów, za dużo opisów, szczególnie przyrody. Oto przykład reakcji ucznia mającego silną motywację zewnętrzną, o dużych kompetencjach literackich, a mimo to niemogącego przełamać trudności w czytaniu Krzyżaków Henryka Sienkiewicza:

\begin{abstract}
„Krzyżacy”, masakra. Nie umiałem zabrać się za tę książkę jakoś. Zabrałem się za późno po pierwsze, żeby ja móc w całości przeczytać, a potem tak czytałem trochę od niechcenia. [...] Nie ciekawiła mnie ta książka. Akcja była trochę za watła. Nie było tej wartkiej akcji, szybkich zmian. No i tak te początkowe 40 stron, które próbują w miarę szybko opisać cała sytuacje, jednak robia to strasznie wolno. To było chyba najdłuższe 40 stron, jakie czytałem. Zajęło mi to naprawde bardzo dużo. Może po prostu skończyłem tę książę jeszcze wtedy, kiedy próbowała wszystko opowiadać, pokazywać, o co chodzi w całym konflikcie między postaciami, i tak dalej. Nie doszedłem po prostu do momentu, w którym zaczęło się coś dziać. Nie przebrnąłem przez ten najnudniejszy moment książki i dlatego wolę się nie wypowiadać na temat „Krzyżaków”. Nie wiem, co się dzieje potem i może to jest dobra książka. [...] „Krzyżaków” sobie wpisałem na taka listę ksiązek, które warto przeczytać albo zabrać się za nia jeszcze raz (G38-3B19-0).
\end{abstract}

\section{W złym momencie}

Wśród odrzucanych lektur szkolnych są te, które polecono czytać, gdy uczniowie albo byli na nie zbyt dojrzali, albo wręcz przeciwnie: za mało doświadczeni czytelniczo, za młodzi. Oto przykład:

- Bo „Kubuś Puchatek” to jest dla bardziej takich jeszcze 7-latków, 6-latków. By ich bardziej interesowało, a trzecioklasistów to już będzie po prostu nudziło. A Tomek Sawyer po prostu nudna książka (P28-6B13-1). 
Jest to istotny sygnał dla nauczycieli. Warto zadbać o to, by lektury szkolne były dostosowane do konkretnego wieku uczniów. Sprzyja temu orientacja nauczyciela w możliwościach percepcyjnych i doświadczeniach lekturowych jego wychowanków. Szczególnie w szkole podstawowej często pojawiać się może utwór zbyt prosty, znany uczniom wcześniej.

\section{Indywidualne potrzeby czytelnicze}

Wyniki opisywanego badania pokazują wspólne preferencje lekturowe nastolatków, ale też wyraźne dowodzą, że szereg utworów czytanych w ramach obowiązku szkolnego zdobywa przeciwstawne oceny. Dobrym przykładem są kanoniczne lektury szkolne - powieści Henryka Sienkiewicza. Wśród młodszych uczniów sprzeczne opinie zyskała (z przewagą niechęci) powieść $W$ pustyni $i$ w puszczy, wśród starszych Krzyżacy. Warto zwrócić uwagę na drugą z nich. Jej tło historyczne może być atrakcyjne dla niektórych chłopców; natomiast dziewczętom powieść przysporzyła więcej kłopotów, najtrudniej było im ją dokończyć i najczęściej wspomagały się streszczeniami. Oto znamienna uczniowska wypowiedź:

„Krzyżacy”... Jest za długa i historyczna ... No, nie wiem, moja przyjaciółka powiedziała, że bardzo jej się podobała ta ksiażka. Ona jest zupełnie inna ode mnie.

Podejrzewam, że inni, też chyba, wydaje mi się, że mało kto ja przeczytał tak naprawdę. Podejrzewam, że wszyscy czytali streszczenia (G35-3B07-1).

\section{Chłopięce i dziewczęce horyzonty oczekiwań}

Dostrzegamy duże zróżnicowanie w uczniowskich strategiach czytelniczych (czytanie utworu w całości, we fragmentach, przeczytanie streszczenia) w zależności od gatunku i tematyki utworów literackich poznawanych obowiązkowo na lekcje języka polskiego. Odnotowano odmienny stosunek dziewcząt i chłopców do lektur: uczennice chętniej czytają dramaty, literaturę obyczajową, chłopcy książki zawierające wątki historyczne. Większe różnice wynikające $\mathrm{z}$ płci dostrzegamy między gimnazjalistami: starsi chłopcy mniej chętnie czytają większość lektur, zwłaszcza klasykę literatury polskiej i obcej, ale także powieści obyczajowe dla młodzieży (Zasacka 2014).

Uczniowie, szczególnie gimnazjaliści, wskazywali na zjawisko nieprzystawalności literatury omawianej w szkole do ich zainteresowań czytelniczych, do wieku, do doświadczeń lekturowych. Jarosław Klejnocki (2013) w artykule o znaczącym tytule Czytanie powinno być przygoda, odnosząc się do swoich doświadczeń pedagogicznych, uważa, że szkolną polonistykę cechuje „odklejenie od realiów rzeczywistości”. Podkreśla nieobecność problematyki bliskiej dylematom dorastania, przeżyć egzystencjalnych, wyborów życiowych, etycznych, które uczniowie napotykają w swoich doświadczeniach czy obserwują w życiu innych, szkolne lektury nie oddają dylematów współczesnego świata. Szczegółowa analiza 
postaw czytelniczych nastolatków pozwala na stwierdzenie, że choć wszyscy narzekają na odległą od współczesności tematykę tekstów szkolnych, to przede wszystkim dziewczęta oczekują od czytanej beletrystyki odpowiedzi na pytania, które sobie zadają w życiu, ilustracji relacji z rówieśnikami, inicjacji miłosnych, rozstań, uniesień i rozczarowań. Chłopcy unikają opowieści, w których obecne są wątek romantyczny, tematyka psychologiczna, dziewczęca albo kobieca główna postać literacka. Tematyka „obyczajowa” jest dla nich nieatrakcyjna, unikają jej świadomie. Jeśli dziewczętom może się podobać beletrystyka obyczajowa opisująca relacje międzyludzkie, codzienne problemy młodzieży, to dla chłopców takie cechy mogą stanowić podstawową przyczynę zniechęcenia do lektury, a nawet przeszkodę w czytaniu, której nie potrafią przezwyciężyć. To kolejny przykład, kiedy wybór lektury zdecydowanie nie przystaje do potrzeb i oczekiwań czytelniczych ucznia. Ofiarą takiego „odklejenia” od chłopięcych (niezależnie od ich kompetencji i doświadczeń czytelniczych) oczekiwań są powieści Lucy M. Montgomery chętnie wybierane przez nauczycieli języka polskiego w szkole podstawowej. Oto przykłady odpowiedzi chłopców z różnych środowisk społecznych, z wiejskich i wielkomiejskich szkół:

No, że nie potrafiłem jej [„Ani z Zielonego Wzgórza”] czytać. Potem dostałem słaba ocenę $z$ testu. Po prostu nie potrafiłem jej czytać, bo nie rozumiałem jej. [...] To była ksiązka psychologiczna i nie za bardzo ja rozumiałem.- „Ania z Zielonego Wzgórza” to doszedłem do środka, ale taka mi trudność sprawiała, że już potem przestałem ja czytać. Już nie mogłem, to właśnie, jedyna książka, która mi zapadła w pamięci, której nie skończyłem, która była tak dla mnie trudna, że nie mogłem, nie chciało mi się jej czytać (P10-6A12-0).

A zauważyłem taki podział w podstawówce jak „Ania z Zielonego Wzgórza” była przy omawianiu. To ja nie przeczytałem, bo mi nie podeszła ta ksiażka zupełnie. W ogóle ciężko mi się ja czytało. Koledzy też nie przeczytali, tylko dziewczyny przeczytały (G35-3B18-0).

„Ania z Zielonego Wzgórza” to nie dla chłopaka, nudna, zero akcji, nic się nie działo, sentymentalna (P24 6C06-0).

\section{Lektury marzeń}

Analiza uczniowskich wypowiedzi pozwala na rekonstrukcję postaw wobec literatury obecnej na lekcjach polskiego i wyodrębnienie wartości przypisywanych cenionym, chętnie czytanym lekturom oraz takim, które by chciano omawiać w szkole. Uczniowskie sądy zostały poddane analizie, której celem było wychwycenie i określenie ich wymowy aksjologicznej (Zasacka 2008, 151-168). Wyodrębniono cztery grupy wartości: hedonistyczne, lekturowe (dotyczące kompozycji i języka) (Straus 2005, 125-126) oraz wartości instrumentalne: poznawcze i moralne. 


\section{Wartości rozrywkowe, eskapistyczne}

Część uczniów w lubianych lekturach szkolnych znajduje wartości rozrywkowe (hedonistyczne). To te, które są odpowiedzialne za dostarczanie przyjemności, wywołanie określonych stanów emocjonalnych. Za Jadwigą Puzyniną można je ulokować wśród wartości „odczuciowych” (Puzynina 2003, 27). Są to wartości autoteliczne: dobrego samopoczucia (cielesnego i duchowego), sprzyjające odprężeniu, relaksowi. Ceniono lekturę za funkcje eskapistyczne, pozwalające uciec od codzienności, zatopić się w innym świecie, utożsamić z bohaterem (Zunchine 2006).W takich okolicznościach, wskazywano na kompozycję utworu, która zawiera „wciągającą akcję", przede wszystkim „przygody”, najczęściej fantastyczne. Wartości te - zazwyczaj przypisywane książkom czytanym w czasie wolnym - jednak nie pojawiają się często jako atrybuty książek szkolnych.

\section{Ciekawa historia, przygody, fantastyczny świat}

Obserwując uczniowskie postawy wobec lektur szkolnych, wyróżnić można jeden wspólny element - zdecydowana większość ceni fantastyczną konstrukcję świata przedstawionego, dla młodszych uczniów ważna jest też szybka, przygodowa akcja:

A dlaczego Ci się podobała „Księga strachów”? - Przygoda, sensacja, bohater taki dociekliwy, spokojny. Ta jego amfibia, ten jego samochód. Miejsce ja sobie tak wyobrażam, że było takie piękne miejsce, to jezioro, chociaż tam niby straszyło, ale po prostu to były zabytki. - A "Szatan z siódmej klasy"- Podobał ci się?- Bardzo... Bo były tam nagłe zwroty akcji, była też taka bardzo ciekawa i widać było, że przeznaczona dla młodzieży (P28-6B13-1).

Wśród obowiązujących lektur, które oceniano w wywiadach indywidualnych jako najbardziej atrakcyjne, uczniowie wskazywali przede wszystkim lektury ze szkoły podstawowej - dotyczy to także gimnazjalistów. Ten fakt może świadczyć o tym, że uczniom gimnazjum trudno jest odnaleźć takie lektury, które rzeczywiście są dla nich interesujące.

Kiedy uczniowie wymieniali książki (również odpowiadając na pytania w ankiecie audytoryjnej), które chcieliby omawiać na lekcjach języka polskiego, swoje rekomendacje czerpali przede wszystkim z najświeższych doświadczeń lekturowych czasu wolnego. Najpoczytniejsza wśród nastoletnich czytelników jest literatura fantastyczna, zwłaszcza ta skierowana do młodzieżowego odbiorcy, a więc z niej były najchętniej wybierane teksty, które mogłyby być czytane w szkole. Również jeśli takie utwory stały się lekturami szkolnymi, najłatwiej zyskiwały akceptację. Wśród dobrze zapamiętanych, wielokrotnie czytanych, a także lubianych lektur ze szkoły podstawowej wyróżnia się cykl Clive’a Staplesa Lewisa Opowieści z Narni. Należy też on do najczęściej czytanych w całości. Przez niektórych był czytany kilkakrotnie, chętnie do niego wracali, chcieli mieć na własność. Wymarzoną lekturą jest cykl przygód Harry'ego Pottera, bezkonkurencyjny, co należy 
podkreślić, i dla chłopców, i dla dziewcząt. Starsi uczniowie jako chcianą lekturę wybierali najczęściej powieści Johna Ronalda Reuela Tolkiena.

Najbardziej zapamiętałem „Hobbita”. Bo to jest taka przygodowa, taka fantastyczna, że czytałem. No mówię, że bardzo lubię przygodowe i takie fantastyczne. Np. „Władce Pierścieni” przeczytałem, „Opowieści z Narni”. I film też pare razy oglądałem „Władcę Pierścieni” (G02-3B20-0).

Tak jak spontaniczne wybory lekturowe, tak i oczekiwania wobec tekstów czytanych z obowiązku różnicuje płeć uczniów. Wśród dziewczęcych rekomendacji do listy lektur szkolnych (dokonywanych na ilościowym etapie badania) najliczniej wybierany był cykl Stephenie Meyer i inne powieści o nastoletnich wampirach. Dwunastoletni chłopcy wskazywali na fantastykę przygodową, o trzy lata starsi młodzieńcy najczęściej wybierali literaturę fantastyczną Johna Ronalda Reuela Tolkiena, Andrzeja Sapkowskiego, Dmitry'a Glukhovsky'go (Zasacka 2014, 113-136) i in.

Ukonstytuował się swoisty kanon utworów fantastycznych cenionych przez nastoletnich czytelników:

Dodałabym na pewno, przynajmniej kawałek, „Władcy pierścieni” lub „Hobbita”, ponieważ to każdy powinien znać...: Przynajmniej kawałek tego, jakiś fragment, ponieważ to raczej jest jedna z najpopularniejszych książek na świecie (P28-6B13-1).

Wśród czytanych w szkole utworów pojawiają się niekiedy powieści kryminalne. Świadczą one, że edukacja polonistyczna poszerzyła zakres projektowanych doświadczeń lekturowych o nowe schematy fabularne i gatunki literackie:

Pod koniec szóstej klasyjako lekturę miałem „10 Murzynków” i „Nie byłojuż nikogo” Agathy Christie i ta książka była jedna $z$ najlepszych, jakie przeczytałem. W moim $\dot{z} y c i u$. [...]. W sensie historia $w$ niej, czyli to po kolei zabijanie kolejnego człowieka według tego wierszyka wydawało mi się jakieś takie fascynujące, ten sam pomysł, żeby tak to zrobić. No i właśnie zaczałem czytać coraz więcej Agathy Christie, a potem przeszedłem te $\dot{z}$ na inne gatunki. Zobaczyłem, że fantastyka nie musi być tylko jedynym takim gatunkiem, który lubię (G38-3A02-0).

Kolejny temat (w tym przypadku spleciony z wartościami moralno-etycznymi) to historia miłosna. Najczęściej czytelniczki odwołują się do dramatu Williama Szekspira:

- Na przykład „Romeo i Julia”. No nie wiem czemu, ale jakoś mi tak się spodobała ta książka i lubię sobie niektóre cytaty nawet na Internecie znaleźć... Jest $w$ niej taka niezwykła miłość, która teraz się już nie zdarza. Taka, że można oddać życie za druga osobę i to jest takie dla mnie takie pełne podziwu i takie fajne no, ciekawe; czytałam dwukrotnie (G05-3B18-1).

\section{Wartości moralno-etyczne}

Wartości moralno-etyczne, stanowiące pewną nadbudowę wartości poznawczych, wymagają interpretacji przez czytelnika aksjologicznego wymiaru dzieła literackiego (Puzynina 2003, 41), poszukiwania w nim wzorów postępowania, wsparcia w odróżnianiu dobra i zła. 
Ważny dla uczniów przekaz wychowawczy w lekturach szkolnych najczęściej dotyczy przyjaźni, lojalności, odwagi, wzorów postaw bohaterskich, patriotycznych, zachowań niezłomnych. Takie wartości znajdowano w ulubionej powieści fantastycznej:

„Lew, czarownica i stara szafa”. Bo przedstawiona była $w$ niej zdrada, nie $w$ przyjaźni, ale $w$ braterstwie. Potem ratunek. Wszystko, jakby miało sens. I ciekawe ogólnie (P236C040).

Na lekcje języka polskiego nieczęsto trafiają utwory chętnie czytane w czasie wolnym, wyjątek stanowi Hobbit Tolkiena i cykl o Harrym Potterze (te powieści czytało obowiązkowo na lekcjach języka polskiego w gimnazjum 3\% uczniów). W powieściach z fantastyki przygodowej uczniowie również potrafią odczytać etyczne wartości: „...w tej lekturze są wartości przyjaźń, lojalność, i Hermiona pilna, dużo się uczyła" (P24-6C03-1).

Rzadziej wskazują na utwory zawierające wzory postaw: związane z życiem we współczesnym świecie, z dorastaniem, patologiami społecznymi. Nie ma wielu lektur szkolnych podejmujących trudne kwestie, jakie zazwyczaj pojawiają się w problemowej prozie obyczajowej dla młodzieży (Biedrzycki i in. 2015). Natomiast wśród wymienianych powieści, w których młodzież odnajduje wartości etyczne, znajdują się Chłopcy z Placu Broni, Kamienie na szaniec, ale też Opowieści z Narni, Władca much. Gimnazjaliści wspominali Kamienie na szaniec Aleksandra Kamińskiego jako lekturę szczególnie cenioną za walory poznawcze, za postawę bohaterów, również za walory lekturowe:

- Że było dużo akcji. Że te akcje przeciwko okupantom były ciekawe, na przykład jakieś akcje sabotażowe, czy coś $w$ tym stylu właśnie. [...] W zasadzie to fajna była jeszcze postawa tych bohaterów, którzy byli tak, można powiedzieć, że byli w stanie poświęcić praktycznie wszystko dla walki z tymi okupantami (G01-3B06-0).

„Kamienie na szaniec”. Ciekawi mnie właśnie tematyka wojenna. I bardzo mi się ta ksiażka podobała. Ciekawia mnie tamte czasy, lubię o tym słuchać, oglądać na przykład tak jak „Czas honoru” był. Ta ksiązka wydawała mi się bardzo ciekawa, wzruszajaca i pouczajaca, to że bohaterowie byli w stanie oddać życie dla ojczyzny (G05-3A02-1).

Tylko niektórym z uczennic brakuje takich utworów, w których mogłyby znaleźć wskazówki, jak żyć, jak lepiej poznać siebie czy zachowania innych:

A co byś dodała, gdybyś mogła dodać jakąś książkę do lektur szkolnych? - Może "Ja Blanka": Bardzo uczaca ksiażka. Uczy patrzenia właśnie na siebie, uczy tego, żeby spojrzeć na siebie $z$ dystansu, żeby naprawdę dodać plusy i minusy swojego charakteru i podsumować (P11-6B18-1).

W opinii niektórych, starszych uczniów lektury szkolne powinny odwoływać się do trwałych, uniwersalnych wartości, skłaniać do myślenia, do refleksji nad postawami bohaterów, pokazywać właściwe zachowania. Jednak są to dosyć ogólne odniesienia, oto przykład: 
[Co mogłoby być lekturą szkolną], to jest ciężko powiedzieć, bo zjednej strony musiałyby zawierać jakieś takie wartości, które by coś pokazywały pewnie. Ale myśle, $\dot{z} e$ „Marley i ja” nie jest akurat złym przykładem na lekturę, ponieważ pokazuje te trwałe wartości, a z drugiej strony jest ciekawy, więc myślę, że uczniowie chętnie będa czytali (G38-3A25-1).

\section{Wartości poznawczo-edukacyjne}

W udzielanych przez uczniów wywiadach trzecią grupą wartości przypisywanych lekturom szkolnym są wartości edukacyjno-poznawcze (Zasacka 2008, 151-167). Oceniając określone utwory literackie, uczniowie za ich zaletę uznawali opisywanie świata realnego i jego problemów. Młodzi ludzie doceniali prezentowanie rzeczywistych problemów, przekazywanie informacji i budowanie wiedzy o świecie. Najczęściej dotyczyło to literatury opartej na faktach albo takiej recepcji beletrystyki, która ujawniała w niej autentyzm, odbicie współczesnej bądź historycznej kultury, obyczajów, a nawet dawnego języka. Ta perspektywa oceny lektur szkolnych należy jednak do rzadkości i tylko niektórzy gimnazjaliści odnajdywali takie wartości:

No nie, bo nawet te lektury szkolne to sq dosyć ciekawe. Na przykład te stare takie, które sq pisane takim językiem nie już współczesnym i też sq ciekawe. Moim zdaniem warto takie książki czytać, żeby podtrzymywać ta kulturę i te książki co były kiedyś (G05-3B18-1).

Jednak nawet świadomość istnienia ważnych wartości poznawczych nie przezwyciężała braku pozytywnych walorów lekturowych:

[Krzyżacy] No, bo to na podstawie historycznych wydarzeń. Chyba ten główny watek nie dzieje się na podstawie historycznej, ale wszystkie wydarzenia sa. Więc dlatego w sumie jest ważna, przez te wydarzenia. - I uważasz, że uczniowie powinni przeczytać?- No, w zasadzie tak. Pomimo tego że nie jest ciekawa. (G05-3B18-1).

„Krzyżacy”. Przeczytałam fragment i trochę nudziła mnie ta ksią̇ka, uważam, $\dot{z}$ e ona jest potrzebna i jest ważna, kiedy ja już omawialiśmy. Wszystkie opisy, zbyt długie (G05-3A02-1).

Dlaczego myślisz, że mimo wszystko warto? - „Krzyżacy” sq w jakimś takim kanonie, wiem wiele o „Krzyżakach”. [Lektury nieukończone] (G38-3B19-0).

Niektórzy uczniowie zwracali uwagę na inny aspekt lektur szkolnych, które ich zdaniem powinny także rozbudzać świadomość narodową i ułatwiać zrozumienie historii Polski, np.:

[Dlaczego „Dywizjon 303” stał się lekturą szkolną?] Myślę, dlatego, że jest o Polakach walczacych $w$ Anglii. To jest takie, jakby pogłębianie wiedzy pod względem historycznym. No też dlatego, że to jest jakby takie wydarzenie, które trzeba pamiętać, który każdy Polak powinien pamiętać. Bo to [było] wtedy, kiedy Polska była okupowana przez Niemców..., bo niektórzy z Polaków nawet nie wiedza o tym (G39-3D21-0). 
Myślę, że "Pana Tadeusza” dobrze zapamiętałem, bo też mnie ciekawi ten świat we wcześniejszych latach, jak się żyło $w$ Polsce. I te wszystkie postacie, język (G39-3F26-0).

Oto kolejne przykłady dostrzegania w lekturach szkolnych ważnych wartości:

Podobały się „Kamienie na szaniec”... To była ciekawa książka, jedyna lektura ciekawa, która przeczytałem...., ona jest oparta na faktach, że jest napisana te $\dot{z} w$ innym stylu, że nie czytałem dotąd jeszcze nigdy takiej ksiażki. To jest jakby, że nie ma tam dialogów, ale wszystko jest opisane, jak ta akcja się rozgrywa. Jakby takie sprawozdanie z pola walki czy jakoś tak można to nazwać - Jak myślisz, co stanowi wartość tej książki? - No nie wiem, musiałbym pomyśleć, ale myślę, że to, że to byli prawdziwi ludzie i byli prawdziwi bohaterowie, a nie wymyślone (G39-3D21-0).

Rzadko - jak wynika z badań (Biedrzycki i in. 2015) - na lekcjach polskiego omawiana jest literatura podejmująca poważne problemy egzystencjalne. Wśród uczniowskich ocen czytanych w szkole tekstów nie pojawiały się często takie sądy, jak przytoczony poniżej, wskazujący na obecność ważnych wartości poznawczych dostrzeżonych w prozie Goldinga:

„Władca much”, bardzo ciężka lektura jak na pierwsza klasę gimnazjum... Przeczytałem tę książkę, też w jeden dzień, bo zapomniałem o niej... Zapamiętałem bardzo dobrze, ponieważ była to bardzo ważna, może opisywała też takie zmiany ludzi, jak się człowiek potrafi zmienić w najgorszych warunkach, jakie moga być, $w$ jakiś sytuacjach granicznych. To było jeszcze na podstawie, opisane o dzieciach. Tym bardziej mnie szokowała ta książka i dlatego mi zapadła w pamięć. (G38-3B19-0).

\section{Zderzenie marzeń z praktyką szkolną}

Wyniki badania czytelnictwa pozwoliły na opisanie wspólnego obszaru szkolnych doświadczeń lekturowych gimnazjalistów i wskazanie tekstów literackich omawianych w pierwszych miesiącach nauki w szóstej klasie szkoły podstawowej. Determinują go i wyczerpują zalecenia podstawy programowej. Do szerszego obiegu czytelniczego przenikają tylko nieliczne tytuły, np. powieści Joanne K. Rowling, które nie należą do spisu lektur sugerowanych przez zapisy programowe, a są cenione przez nastoletnich czytelników. Dyskusja na lekcjach języka polskiego o pozaszkolnych tekstach zdarza się sporadycznie. Jednocześnie widoczny jest wraz z dorastaniem uczniów wzrost niechęci do lektur szkolnych i spadek siły odczuwania potrzeb czytelniczych.

Nauczyciel dokonujący doboru lektur i sposobów ich omawiania powinien być świadomy odmiennych oczekiwań wobec literatury pięknej chłopców i dziewcząt. Dziewczęta czytają więcej, mają szersze doświadczenia lekturowe, można tu użyć określenia Richarda M. Petersona i Rogera A. Kerna, że są „wszystkożerne” (Peterson, Kern 1996). Oznacza to, że podejmują się odbioru literatury wymagającego różnych „gier z tekstem" (Martuszewska 2007), różnych kompetencji literackich. W efekcie 
dla czytelniczek mogą być atrakcyjne różne konwencje i gatunki literackie. Łatwiej identyfikują się z bohaterami i współodczuwają z nimi, sprzyja to zaangażowanej lekturze. Czytają utwory z różnych obszarów, np. romans Nicholasa Sparksa, powieści Jane Austen, Stephena Kinga, Małgorzaty Musierowicz, Joanne K. Rowling, Stephenie Meyer (Zasacka 2012, 2014). W odróżnieniu od chłopców posiadają inne oczekiwania wobec lektury: często wprost szukają w niej przesłania, chcą się dowiedzieć np. o tym, jak inni radzą sobie z trudnościami, jak to jest, kiedy doświadcza się cierpienia, jak można je przezwyciężyć. Część gimnazjalistek szuka literatury problemowej: obrazującej doświadczenia nastoletnich narkomanów, prezentującej dzienniczek bulimiczki etc. Chłopcy, jeśli poszukują w książkach odwzorowania rzeczywistości, to wówczas interesująca jest dla nich tematyka historyczna. Chętniej jednak wybierają utwory sprzyjające recepcji eskapistycznej, ważny jest też dla nich męski bohater, cenią sobie poczucie humoru, małe i wielkie przygody. Bardziej doświadczeni czytelniczo chłopcy sięgają po trudniejszą fantastykę, czarną fantasy, antyutopie etc. Znajdują tam wzory postaw.

\section{Implikacje dla dydaktyki polonistycznej}

Analizy wyników czytelnictwa dzieci i młodzieży przynoszą szereg wniosków i zaleceń dla nauczycieli polonistów. Podstawowe związane jest z odmową przez dużą grupę uczniów czytania lektur szkolnych bądź, pomimo podjęcia lektury, rezygnacji z dokończenia jej czytania lub wspieranie się streszczeniami. Nastolatkom tym zabrakło kompetencji czytelniczych, wiary, że przezwyciężą napotkane przeszkody w czytaniu. Tekst nie rozbudził ich zainteresowania, a potrzeba otrzymania dobrego stopnia i pochwały za jego poznanie okazała się niewystarczająca. Badanie ujawniło też niebezpieczną tendencję: nawet uczniowie posiadający bogate pozaszkolne doświadczenia czytelnicze - rozbudzone motywacje wewnętrzne do czytania literatury pięknej, rezygnują z realizacji szkolnego obowiązku lekturowego. Należy także podkreślić, że w grupie niechętnych czytaniu lektur szkolnych znacznie więcej jest chłopców, szczególnie uczniów gimnazjum, pochodzących z bardzo różnych środowiskach społeczno-kulturowych.

Wyniki badania wskazują na konieczność odniesienia się na lekcjach języka polskiego do wszystkich elementów budujących motywacje czytelnicze (Zasacka 2014, 72-85): samooceny własnych umiejętności czytelniczych i skłonności do pokonywania bądź unikania przeszkód; motywacji wewnętrznej związanej z zaciekawieniem samym tekstem i umiejętnością zaangażowania się w jego czytanie; motywacji zewnętrznych świadczących o czytaniu dla nagrody i czwartego komponentu mówiącego o relacjach społecznych towarzyszących praktykom czytelniczym. Zaangażowani czytelnicy (Guthrie, Alao, Reinehart 1997, 439) to ci, którzy są zaciekawieni 
tematyką utworu i chcą go poznać. Towarzyszy im przekonanie, że czytanie i zrozumienie tekstu nie stanie się dla nich zbyt trudne. Potrafią też dzielić się z innymi wrażeniami z lektury.

Motywacjom czytelniczym sprzyja samodzielny wybór lektury. Nauczyciel w szkole podstawowej posiada pełną swobodę doboru tytułów, ogranicza go tylko konieczność kształtowania umiejętności wskazanych w podstawie programowej, decydujący jest sposób omawiania wybranych tekstów. Istnieje też możliwość, a nawet wymóg, wyboru części utworów wspólnie $\mathrm{z}$ uczniami. Jest to szansa na upodmiotowienie ucznia, dialog z nim, poznanie go jako czytelnika nie tylko szkolnego. Jednocześnie jest to okoliczność sprzyjająca uwzględnieniu indywidualnych oczekiwań i zainteresowań uczniów z konkretnej klasy. Obecność na lekcjach szkolnych tekstów czytanych poza szkołą pozwoli nie tylko wykorzystać uczniowskie kompetencje zdobyte w czasie spontanicznej lektury, ale także ukierunkować je, wskazać na możliwe tropy interpretacyjne, uczyć krytycznej oceny literatury. Jest to także szansa na poruszanie problemów i pytań egzystencjalnych dręczących nastolatków i uświadomienie im, że mogą szukać odpowiedzi na nie $\mathrm{w}$ literaturze. Wszystkie te zabiegi sprzyjają odwołaniu się do czytelniczych motywacji wewnętrznych (Brophy 2010), pomagają zmniejszyć dystans między szkolnym i pozaszkolnym czytaniem.

Jednocześnie, jeśli nawet tylko część uczniów aktywnie czyta w czasie wolnym i ma własne pomysły, co warto wybrać, to ich przykład i rekomendacje mogą zachęcić kolegów - czytelników opornych. Wspólny wybór tekstów czytanych w klasie pozwala uruchomić rówieśniczy autorytet. Opinie rówieśników, szczególnie dla dorastającej młodzieży, mają największą moc oddziaływania (Zasacka 2014, 137-152). Mogą być decydującym wsparciem dla nauczyciela dążącego do tego, by tekst na lekcji był odczytywany w sposób pogłębiony. Warto więc tworzyć sytuacje wymiany i krzyżowania opinii o literaturze, może to sprzyjać uaktywnieniu części wycofanych uczniów.

W okolicznościach, kiedy lekturą szkolną powinien być utwór literacki należący do klasyki, wskazane są zajęcia przygotowawcze zanim uczeń zostanie pozostawiony sam na sam z tekstem. Oznacza to, że konieczne są dwojakie zabiegi. Po pierwsze wyjaśnienia dotyczące specyfiki danego utworu, elementów, które mogą być niezrozumiałe bądź nieoczywiste dla ucznia, np. związane z gatunkiem utworu, jego tłem historycznym, obecną $\mathrm{w}$ nim frazeologią etc. Po drugie należy zaintrygować ucznia danym tekstem, wskazać przyczyny, dla których został wybrany. Zasugerować, co może być w nim atrakcyjne i pouczające dla współczesnego czytelnika. W tym celu mogą być wykorzystane przykłady konkretnych wątków, fragmentów czy opisy emocji, które tekst może ewokować, losy recepcji danego utworu bądź konteksty jego powstania, etc. W zależności od wieku, płci uczniów i charakteru utworu literackiego warto 
szukać tych jego cech mogących zainteresować konkretnego odbiorcę, poszukiwać pomysłów na przełamywanie i antycypowanie uczniowskiego oporu.

Elementem sprzyjającym odmowie czytania obowiązkowych lektur jest przewidywalna forma egzekwowania ich znajomości. Sprawdziany, które dążą do przyłapania na nieznajomości jakiegoś detalu, zniechęcają do czytania. Szczególnym wyzwaniem dla nauczyciela jest zbudowanie takiej sytuacji, aby uczeń, który nie przeczytał lektury, miał poczucie, że coś stracił, coś go ominęło, że przez to czegoś nie zrozumiał, o czymś się nie dowiedział, nie miał szansy na uczestniczenie w ożywionej dyskusji związanej z interpretacją książki.

\section{Bibliografia:}

Biedrzycki Krzysztof, i in., 2015, Dydaktyka literatury i języka polskiego $w$ gimnazjum $w$ świetle nowej podstawy programowej. Raport $z$ badania, Warszawa.

Bordzoł Piotr, Zasacka Zofia, 2014, Nauczyciele języka polskiego, w: Licza się nauczyciele. Raport o stanie edukacji 2013, Warszawa, s. 161-184.

Brophy Jere, 2010, Motywowanie uczniów do nauki, Kruszewski K. (przeł), Warszawa.

Guthrie John T., Alao Solomon, Rinehart Jennifer M., Engagement in reading for young adolescents, "Journal of Adolescent and Adult Literacy" 40, s. 438-446.

Guthrie John T., Wigfield Alan, 2000, Engagement and motivation in reading, w: Handbook of reading research: Volume III , Kamil M.L., Mosenthal P.B., Pearson P.D., \& Barr R. (red.), New York, s. 403-422.

Klejnocki Jarosław, 2013, Czytanie powinno być przygoda, „Polonistyka”, nr 6, s. 8-9.

Martuszewska Anna, 2007, Radosne gry. O grach/zabawach literackich, Gdańsk.

Peterson Richard, A., Kern Roger, M., 1996, Changing Highbrow Taste: From

Snob to Omnivore, „American Sociological Review”, nr 5, s. 900-907.

Puzynina Jadwiga, 2003, Miejsce wartości w językowym obrazie świata, w: Bartmiński J. (red.), Język w kręgu wartości. Studia semantyczne, Lublin.

Straus Grażyna, 2005, Modelowi sukcesorzy, indywidualiści, eklektycy, Warszawa.

Zasacka Zofia, 2008, Nastoletni czytelnicy, Warszawa.

Zasacka Zofia, 2012, Natolatki i książki - od czytania codziennego do unikania, „Edukacja” nr 2, s. 20-36.

Zasacka Zofia, 2014, Czytelnictwo dzieci i młodzieży, Warszawa.

Zunshine Lisa, 2006, Why we read fiction. Theory of mind and novel, The Ohio State University Press, Columbus 2006. 


\section{O Autorce:}

Zofia Zasacka, adiunkt w Instytucie Badań Edukacyjnych w Pracowni Języka Polskiego oraz Instytucie Książki i Czytelnictwa Biblioteki Narodowej. Zajmuje się socjologią kultury, socjologią młodzieży i edukacji. Interesują ją kultura i literatura popularna oraz ich miejsce we współczesnej edukacji. Obserwuje przemiany w stylach życia i formach uczestnictwa w kulturze, szczególnie pod wpływem Internetu i nowych mediów. Analizuje zajmowane w nich miejsce praktyk czytelniczych, zwłaszcza w środowiskach młodzieżowych. Prowadzi badania nad czytelnictwem dzieci i młodzieży. Jest autorką szeregu publikacji prezentujących wyniki tych badań. 